\title{
Analisis Strategi Pemasaran Dalam Meningkatkan Volume Penjualan pada Shopie Paris BC. Yenni Kecamatan Muara Bulian
}

\author{
Ade Jermawinsyah Zebua ${ }^{1}$ \\ STIE Graha Karya Muara Bulian ${ }^{1}$
}

\begin{abstract}
Absract
At this time the competition in the business world is felt increasingly competing, along with the increase of similar companies that offer the same product. The purpose of this study is to determine what factors affect the increase in sales volume in Shopie Paris Bc. Yenni in Muara Bulian. The method of analysis is qualitative descriptive. Data collection in this research is using library research and field research. Types of data used in this study are primary and secondary data. Based on the research that Strategis of marketing in an effort to increase sales volume at Shopie Paris Bc. Yenni in Muara Bulian are product strategy, price, promotion, place and people. Sale of Shopie Paris Bc. Yenni in Muara Bulian in 2015 decreased sales by $-0.5 \%$, while in 2013 sales at the highest position with a value of $0.2 \%$. It is recommended that Shopie Paris Bc. Yenni in Muara Bulian more attention to the problem of distribution of goods to consumers. For promotional aspects should be more developed again, meaning in addition to MLM promotion method can be done by opening the booth in front of self-service and can provide training to members about how to market the product.
\end{abstract}

Keywords: product strategy, price strategy, promotion strategy, place strategy and people strategy

\section{PENDAHULUAN}

Persaingan di dunia bisnis dewasa saat ini dirasakan semakin ketat, seiring dengan bertambahnya perusahaanperusahaan yang sejenis yang menawarkan produk yang sama. Masyarakat semakin membutuhkan produk-produk yang berkualitas dalam memenuhi kebutuhannya, mereka semakin jeli untuk melihat mana produk yang berkualitas dan mana yang tidak. Dalam hal ini setiap perusahaan hendaknya mengetahui pasar, dimana produk atau jasa yang di produksi akan di tawarkan atau di pasarkan (Umar, 2005)

Tujuan tersebut dapat dicapai dengan usaha mempertahankan dan meningkatkan keuntungan atau laba perusahaan. Usaha yang umum dilakukan untuk meningkatkan laba perusahaan yaitu dengan mencari dan membina pelanggan, serta usaha menguasai pasar. Usaha tersebut tidak lepas dari peranan bagian pemasaran perusahaan dalam melakukan strategi yang bagus untuk dapat menggunakan kesempatan atau peluang yang ada dalam pemasaran, sehingga posisi perusahaan di pasar dapat di pertahankan sekaligus ditingkatkan (Gitosudarmo, 2008)

Keberhasilan penjualan setiap perusahaan ditentukan melalui bagaimana perusahaan melakukan strategi pemasaran yang efisien dan mempelajari apa yang dibutuhkan dan diinginkan oleh konsumen serta mengetahui apa saja yang dapat memberi keuntungan dalam sebuah usaha, sehingga usaha dapat berjalan sesuai dengan apa yang sudah di rencanakan. Menurut Suntoyo (2013) strategi pemasaran pada dasarnya rencana yang menyeluruh, terpadu dan menyatu dibidang pemasaran, yang memberi panduan tentang kegiatan yang dilakukan untuk dapat tercapainya tujuan pemasaran suatu perusahaan.

Strategi pemasaran mempunyai peranan penting untuk mencapai keberhasilan usaha, oleh karena itu bidang pemasaran berperan besar dalam merealisasikan rencana usaha. Hal ini 
dapat dilakukan, jika perusahaan ingin mempertahankan dan meningkatkan penjualan produk atau jasa yang mereka produksi. Dengan melakukan penerapan strategi pemasaran yang akurat melalui pemanfaatan peluang dalam meningkatkan penjualan, sehingga posisi atau kedudukan perusahaan di pasar dapat ditingkatkan atau dipertahankan. Sehubungan dengan hal tersebut pelaksanaan pemasaran modern dewasa ini mempunyai peranan yang besar sebagai penunjang langsung terhadap peningkatan laba perusahaan. Strategi pemasaran harus dapat memberi gambaran yang jelas dan terarah tentang kegiatan yang akan dilakukan perusahaan dalam memaksimalkan setiap kesempatan atau peluang pada beberapa pasar sasaran (Assauri, 2007)

Dalam strategi pemasaran terdapat istilah Bauran Pemasaran (Marketing Mix). Bauran pemasaran merupakan cara dimana pengusaha dapat mempengaruhi konsumennya yang memerlukan perencanaan dan pengawasan yang matang serta perlu dilakukan tindakan-tindakan yang konkret (Gitosudarmo, 2001). Untuk keperluan tersebut pengusaha dapat melakukan tindakan-tindakan yang terdiri dari 4 macam, yaitu tindakan mengenai produk (product), Harga (price), distribusi atau penempatan produk (place) dan promosi (promotion) (Kasmir, 2003)

Sedangkan menurut Kotler dan keller yang di terjemahkan oleh Benyamin Molan, Bauran pemasaran adalah perangkat alat pemasaran yang digunakan untuk mengejar tujuan perusahaannya. (Kotler, 2002)

Adapun variabel bauran pemasaran tersebut yaitu :

\section{Produk}

Produk adalah sesuatu yang dapat memenuhi kebutuhan dan keinginan konsumen. Sesuatu yang dapat di tawarkan ke pasar untuk mendapatkan perhatian untuk di beli, digunakan atau di konsumsi yang dapat memenuhi keinginan dan kebutuhan (Kotler, 2002). Strategi produk yang dilakukan oleh suatu perusahaan dalam mengembangkan produknya yaitu (Kasmir, 2003) :

\section{a. Penentuan Logo dan Motto}

Logo merupakan ciri khas suatu produk, sedangkan motto merupakan serangkaian kata-kata yang berisikan visi dan misi perusahaan dalam melayani masyarakat. Baik logo ataupun motto harus dirancang dengan benar, pertimbangan pembuatan logo dan motto yaitu: logo dan motto harus menarik dan mudah diingat.

\section{b. Menciptakan Merek}

Merek produk merupakan suatu tanda atau simbol yang memberikan identitas suatu produk tertentu yang dapat berupa kata-kata, gambar atau kombinasi keduanya. Tidak lupa harus memperhatikan faktor-faktor dalam menciptakan merek agar lebih menarik merek harus mudah diingat, terkesan hebat dan modern serta menarik perhatian konsumen.

\section{c. Menciptakan Kemasan}

Kemasan merupakan pembungkus suatu produk, penciptaan kemasanpun harus memenuhi berbagai persyaratan seperti kualitas kemasan, bentuk dan warna dari kemasan tersebut.

\section{d. Keputusan Label}

Label merupakan sesuatu yang di lekatkan pada produk yang ditawarkan dan merupakam bagian dari kemasan. Label harus menjelaskan siapa yang membuat, dimana dibuat, kapan dibuat, cara menggunakan, waktu kadaluarsa dan informasi lainnya.

\section{Harga}

Harga adalah jumlah yang dibutuhkan untuk mendapatkan sejumlah kombinasi dari barang beserta pelayanannya. Penentuan harga sangat penting untuk diperhatikan, mengingat harga merupakan salah satu penyebab laku tidaknya produk dan jasa yang ditawarkan. Salah dalam menentukan harga akan berakibat fatal terhadap produk yang ditawarkan dan dapat berakibat tidak lakunya produk tersebut dipasar(Swastha, 
2008). Oleh karena itu penentuan harga oleh suatu perusahaan dimaksudkan dengan berbagai tujuan yang hendak dicapai, tujuan penentuan harga secara umum adalah sebagai berikut (Kasmir, 2003):

\section{a. Untuk Bertahan Hidup}

Dalam hal ini tujuan menentukan harga semurah mungkin dengan maksud agar produk atau jasa yang ditawarkan laku di pasaran, dengan catatan harga murah tapi masih dalam kondisi yang menguntungkan.

\section{b. Untuk Memaksimalkan Laba}

Tujuan harga ini dengan mengharapkan penjualan yang meningkat sehingga laba dapat ditingkatkan. Penentuan harga biasanya dapat dilakukan dengan harga murah atau tinggi.

c. Untuk Memperbesar Market Share.

Penentuan harga ini dengan harga yang murah sehingga diharapkan jumlah pelanggan meningkatkan dan diharapkan pula pelanggan pesaing beralih ke produk yang ditawarkan.

\section{d. Mutu produk}

Tujuan adalah untuk memberikan kesan bahwa produk atau jasa yang ditawarkan memiliki kualitas yang tinggi atau lebih tinggi dari kualitas pesaing. Biasanya harga ditentukan setinggi mungkin. Karena masih ada anggapan bahwa produk yang berkualitas adalah produk yang harganya lebih tinggi dari harga pesaing.

\section{e. Karena pesaing}

Dalam hal ini penentuan harga dengan melihat harga pesaing. Tujuannya adalah agar harga yang ditawarkan jangan melebihi harga pesaing.

\section{Promosi}

Promosi merupakan kegiatan untuk mempengaruhi konsumen agar mereka mengetahui dan mengenal produk yang di tawarkan oleh perusahaan kepada mereka dan kemudian mereka tertarik ingin mencoba lalu membeli produk tersebut (Gitosudarmo, 2001).
Kegiatan promosi ini perusahaan berusaha untuk mempromosikan seluruh produk dan jasa yang dimilikinya, baik langsung maupun tidak langsung. Tanpa promosi jangan diharapkan pelanggan dapat mengenal produk atau jasa yang ditawarkan. Oleh karena itu promosi merupakan cara yang paling ampuh untuk menarik dan mempertahankan konsumennya. Salah satu tujuan promosi perusahaan adalah menginformasikan segala jenis produk yang ditawarkan dan berusaha menarik calon konsumen yang baru (Hermawan, 2002)

Lima sarana promosi utama Kotler dan Amstrong adalah sebagai berikut (Kotler, 2008)

a. Periklanan (advertising)

$$
\text { Kegiatan promosi yang }
$$

digunakan oleh perusahaan guna menginformasikan, menarik dan mempengaruhi calon konsumennya menggunakan brosur, spanduk, iklan di media cetak, tv maupun radio.

b. Promosi penjualan (sales promotion)

Agar konsumen tertarik membeli produk atau jasa yang ditawarkan maka perlu dilakukan promosi yang menarik seperti pemberian harga khusus atau discount untuk produk tertentu, memberikan undian kepada pembeli yang membeli dalam jumlah tertentu atau memberikan cinderamata kepada pembeli.

c. Publisitas (publicity)

Publisitas adalah kegiatan promosi untuk memancing konsumen melalui kegiatan seperti pameran dan bakti sosial. Kegiatan publisitas bertujuan untuk membuat pamor perusahaan baik dimata konsumennya.

d. Penjualan Personal (personal selling)

Presentasi pribadi oleh salesman atau salesgirl perusahaan untuk tujuan menghasilkan penjualan dan membangun hubungan dengan konsumen.

e. Pemasaran langsung (direct marketing)

Hubungan langsung dengan konsumen individual yang ditargetkan secara cermat untuk memperoleh respons 
segera dan membangun hubungan pelanggan yang langgeng. Bauran promosi ini digunakan untuk mengkomunikasikan kegiatan perusahaan kepada konsumen. Komunikasi yang efektif akan mengubah tingkah laku konsumen dan akan memperkuat tingkah laku yang telah diubah sebelumya.

\section{Tempat (Place)}

Tempat adalah kegiatan perusahaan yang membuat produk tersedia bagi sasaran. Tempat merupakan saluran distribusi yaitu serangkaian organisasi yang saling tergantung yang saling terlihat dalam proses untuk menjadikan produk atau jasa siap untuk digunakan atau dikonsumsi. Lokasi berarti berhubungan dengan dimana perusahaan harus bermarkas dan melakukan operasi. Perusahaan sebaiknya memilih tempat yang mudah dijangkau dengan kata lain strategis (Kotler, 2006)

Kotler dan amstrong juga menambahkan dalam pemasaran jasa memiliki alat pemasaran tambahan seperti people (manusia), physical evidence (fasilitas fisik) dan process (proses), sehingga dikenal dengan istilah 7P.

\section{Manusia (people)}

Yaitu orang yang ikut terlibat baik langsung maupun tidak langsung pada proses layanan itu sendiri. Elemen dari manusia adalah pegawai perusahaan, konsumen, dan konsumen lain. Semua sikap dan tindakan yang dilakukan karyawan akan mempengaruhi keberhasilan penyampaian jasa.

Strategi pemasaran menurut Suntoyo (2013) menyatakan bahwa strategi pemasaran pada dasarnya rencana yang menyeluruh, terpadu dan menyatu dibidang pemasaran, yang memberi panduan tentang kegiatan yang dilakukan untuk dapat tercapainya tujuan pemasaran suatu perusahaan.

Menurut Swath (2008) promosi pada dasarnya merupakan arus informasi atau persuasi satu arah yang dibuat untuk mengarahkan seseorang atau organisasi pada tindakan yang menciptakan pertukaran dalam pemasaran. Dalam melaksanakan promosi, suatu perusahaan dapat menggunakan berbagai sarana seperti periklanan, personal selling, promosi penjualan, dan publisitas. Sarana yang dipakai dalam promosi tergantung berapa faktor seperti dana, sifat pasar, jenis produk. Oleh karena itu perusahaan harus mampu memilih sarana-sarana dan media apa yang paling tepat untuk kegiatan promosinya serta kombinasi dari semua sarana media yang ada.

Salah satu gerakan ekonomi yang sedang berkembang pesat saat ini adalah MLM (Multi Level Marketing). MLM merupakan sebuah metode pemasaran barang dan atau jasa dari sistem penjualan barang langsung melalui program pemasaran berbentuk lebih dari satu tingkat, di mana mitra usaha mendapatkan komisi penjualan dan bonus penjualan dari hasil penjualan barang dan atau jasa yang dilakukannya sendiri dan anggota jaringan di dalam kelompoknya (Kuswara, 2005)

Bisnis MLM seringkali dikaitkan dengan sebuah formula untuk mendapatkan kekayaan secara cepat dan mudah. Pandangan seperti ini muncul, mungkin salah satunya akibat dari beberapa penawaran usaha-usaha MLM yang menghubungkan bisnis ini dengan cara cepat dan mudah untuk mendapatkan kekayaan. Akhirnya banyak orang menganggap hal ini sebagai suatu kebenaran. Sebenarnya, MLM bukan sebuah formula ajaib yang bisa mendatangkan uang dengan cepat dan mudah. MLM hanya sebuah metode untuk memasarkan suatu produk yang berbeda dengan cara-cara konvensional. MLM hanyalah suatu metode bisnis alternatif yang berhubungan dengan pemasaran dan distribusi (Kuswara, 2005)

Dalam penelitian ini penulis mengambil tempat penelitian di Shopie Paris Bc. Yenni Kecamatan Muara Bulian, dimana usaha ini bergerak dalam bidang pemasaran. Shopie Paris merupakan 
perusahaan multi level marketing (MLM) yang beroperasi di Indonesia sejak tahun 1994. Produk yang ditawarkan oleh Shopie Paris adalah produk-produk yang berstandar SNI yang telah ditetapkan pemerintah. Usaha yang di kelola oleh ibu RTS. Yenni Purnama Sari ini didirikan pada tahun 2010 yaitu melalui open stand/bazaar di depan mini market Divo dan diresmikan Shopie Paris pada tanggal 1 Juni 2011, awal berdirinya lokasi usaha berada di Jl. Jend.Sudirman, BBC B-17 Kecamatan Muara Bulian, Kabupaten Batang Hari. Untuk pemasarannya distributor wilayah mempunyai member yang tersebar diseluruh wilayah kabupaten Batang Hari. Member dalam penelitian ini adalah jaringan pemasaran yang dapat diperluas usaha.

Dikarenakan Shopie Paris merupakan perusahaan multi level marketing (MLM) maka distributor wilayah juga menerima pendaftaran member, dengan adanya member maka usaha ini lebih akan cepat dikenal atau diketahui oleh setiap kalangan masyarakat baik yang dari kalangan anak-anak, dewasa dan orang tua, membernya pun selalu meningkat. Meningkatnya volume penjualan di Shopie Paris yang dikelola oleh ibu Yenni tergantung meningkatnya membernya. Pada tahun 2013 sampai 2016 membernya tercatat sejumlah 5.112 orang. Berikut data volume penjualan pada Shopie Paris Bc. Yenni Kecamatan Muara Bulian Tahun 2013-2016

Tabel 1 Data volume penjualan Tahun 2013-2016

\begin{tabular}{ccc}
\hline No & Tahun & Volume Penjualan (Rp) \\
\hline 1 & 2013 & 3.000 .000 .000 \\
2 & 2014 & 3.600 .000 .000 \\
3 & 2015 & 1.800 .000 .000 \\
4 & 2016 & 2.400 .000 .000 \\
\hline
\end{tabular}

Sumber: Data tahun 2018

Berdasarkan tabel 1 diatas dapat dinyatakan bahwa peningkatan volume penjualan pada tahun 2014 tercatat berada pada tingkat tertinggi, untuk volume penjualannya berjumlah Rp 3.600.000.000 dan volume penjualan pada tahun 2015 tercatat berada pada tingkat terendah yaitu Rp 1.800.000.000 Adapun tujuan dari penelitian ini adalah untuk mengetahui perkembangan volume penjualan pada Shopie Paris Bc Yenni Muara Bulian, untuk mengetahui strategi pemasaran Shopie Paris Bc Yenni Muara Bulian, untuk menganalisis strategi pemasaran dalam meningkatkan volume penjualan pada Shopie Paris Bc Yenni Muara Bulian.

Setelah merumuskan seluruh strategi pemasarannya, perusahaan siap memulai merencanakan rincian bauran pemasaran, salah satu konsep utama dalam pemasaran modern. Definisi bauran pemasaran (marketing mix) adalah kumpulan alat pemasaran taktis yang dipadukan perusahaan untuk menghasilkan respons yang diinginkannya yang terdiri dari himpunan variabel yang dapat dikendalikan dan digunakan oleh perusahaan untuk mempengaruhi tanggapan konsumen dalam pasar sasarannya. Variabel atau kegiatan tersebut perlu dikombinasikan dan dikoordinasikan oleh perusahaan agar dapat melaksanakan program pemasaran secara efektif (Kotler, 2008)

Menurut Basu Swastha definisi bauran pemasaran (marketing mix) adalah kombinasi dari 4 variabel atas kegiatan yang merupakan inti dari sistem pemasaran perusahaan yaitu produk, struktur harga, kegiatan promosi dan sistem distribusi (Swastha, 2008)

\section{METODE PENELITIAN}

Penelitian ini menggunakan studi kasus, penelitian dilakukan terhadap objek tertentu dimana kesimpulan yang nantinya dibuat hanya pada objek yang diteliti.

Jenis data yang digunakan dalam penelitian ini adalah data primer dan sekunder. Data primer diterima langsung dari lapangan menggunakan metode yaitu observasi dan interview. Data sekunder 
diperoleh dengan studi perpustakaan yang meliputi literature. Sumber data diperoleh dari Shopie Paris Muara Bulian.

Metode pengumpulan data dalam penelitian ini adalah library research (studi keperpustakaan) dan field research (penelitian lapangan). Metode analisa yaitu deskriptif kualitatif (Moleong,2002) yaitu suatu metode yang berfungsi untuk membuat deskrisi atau gambaran secara sistematis dan aktual mengenai fakta-fakta yang ada di lapangan dikumpulkan dan dikelompokan serta disusun sedemikian rupa untuk dibandingkan dengan teori-teori yang relevan sehingga dapat di ambil suatu kesimpulan.

Untuk menghitung perkembangan penjualan pada Shopie Paris Bc. Yenni ini menggunakan turunan rumus pertumbuhan ekonomi pertahun dari Horne, dkk (2005):

$\mathrm{PJ}=\frac{\text { Penjualan Tahun ini-Penjualan Tahun lalu }}{\text { Penjualan Tahun lalu }} \times 100 \%$

\section{HASIL DAN PEMBAHASAN}

Data yang diolah adalah penjualan produk 4 tahun berjalan, dengna data dimulai dari bualan Januari 2013 sampai desember 2016, berdasarkan pada tabel 1.1 dapat diketahui bahwa perkembangan volume penjualan pada Shopie Paris Bc. Yenni Kecamatan Muara Bulian dalam 4 tahun dapat dijelaskan sebagai berikut:

a. Peningkatan Volume penjualan dari tahun 2013 ke tahun 2014 sebesar 0,2\%

b. Volume penjualan dari tahun $2014 \mathrm{ke}$ tahun 2015 mengalami penurunan yang cukup signifikan yaitu turun hingga $0,5 \%$. Penurunan volume penjualan ini salah satunya disebabkan oleh menurunnya penghasilan dari para petani sawit dan sawit seluruh Kabupaten Batang Hari

c. Peningkatan volume penjualan dari tahun 2015 ke tahun 2016 sebesar $0,34 \%$

Dalam strategi pemasaran Shopie Paris Bc. Yenni melakukan 4 strategi yakni strategi produk, harga, distribusi dan promosi.
Analisa Strategi Produk, Produk yang ada dalam Shopie Paris Bc. Yenni Kecamatan Muara Bulian yaitu tas, dompet, pakaian, sepatu, sandal, jam tangan, ikat pinggang, kacamata, aksesoris, kosmetik dan perawatan kulit. Pada tanggal 11 Agustus 2017 Shopie Paris Bc. Yenni telah berhasil mengeluarkan produk baru bernama Sunday, dalam katalog Sunday ini berisi semua produk home living terlengkap seperti mulai dari elektronik perlengkapan dapur, keperluan alat kantor, hingga nutrisi kesehatan dengan produk yang terjamin dan terpenting bergaransi, katalog Sunday terbitnya sama dengan katalog Shopie Paris yang setiap 30 hari.

Analisa Strategi Price, Penetapan harga sebenarnya cukup kompleks dan sulit, memerlukan pendekatan yang simpatik yang melibatkan penetapan umum dan pengembangan suatu struktur harga yang tepat. Karena penetapan harga suatu produk dapat mempengaruhi keberhasilan pemasaran produk yang dihasilkan. Penetapan harga pada Shopie Paris Bc. Yenni Kecamatan Muara Bulian sesuai dengan harga didalam katalog Shopie. Jika menjadi anggota member Shopie yang ditandai kartu member, maka diberikan potongan harga sebesar 30\% dikurangi dari harga katalog yang ada. Harga bonus dihitung sebesar 60\% dari harga katalog Shopie yang tercantum dalam katalog. Untuk itu perusahaan Shopie Paris Bc. Yenni Kecamatan Muara Bulian telah tepat dalam menetapkan harga, hanya saja tinggal mengembangkan bonus yang lebih banyak.

Analisa Strategi Place, Usaha Shopie Paris Bc. Yenni Kecamatan Muara Bulian dalam penjualan dan pemasarannya mendistribusikan produknya kepada produsen secara langsung dan tidak langsung. Penggunaan distribusi secara langsung sudah cukup efektif karena konsumen bisa langsung datang ketempat usaha Shopie Paris Bc. Yenni Kecamatan Muara Bulian tetapi dalam meningkatkan 
volume penjualan system ini kurang menguntungkan karena sulit untuk meraih konsumen yang lebih besar. Untuk itu juga dilakukan saluran distribusi tidak langsung melalui member yang telah terdaftar menjadi anggota Shopie Paris Bc. Yenni Kecamatan Muara Bulian yang akan menjual produk Shopie Paris kepada konsumen. Sistem distribusi secara tidak langsung untuk usaha Shopie Paris Bc. Yenni Kecamatan Muara Bulian dapat dikembangkan lagi karena pendistribusiannya masih terbatas yang ada di Kecamatan Muara Bulian saja agar dapat meluas ke daerah lain sehingga produk Shopie Paris mudah diperoleh. Dengan demikian pemilihan saluran distribusi langsung dan tidak langsung pada usaha Shopie Paris Bc. Yenni Kecamatan Muara Bulian sangat tepat sehingga bisa dikembangkan.

Analisa Strategi Promosi, Dalam mempromosikan Shopie Paris Bc. Yenni Kecamatan Muara Bulian menggunakan 3 (tiga) indikator promosi antara lain:

1. Periklanan

2. Promosi penjualan

3. Personal Selling

Kegiatan promosi lainnya dengan cara memperkenalkan produk diberbagai jalan raya seperti membuka bazaar Shopie Paris yang tempatnya dekat dengan pusat pembelanjaan yang ramai dikunjungi konsumen, sehingga penyampaian dari mulut ke mulut dari konsumen yang membeli produk Shopie Paris ini dapat dikembang. Usaha Shopie Paris Bc. Yenni ini bukan hanya melakukan promosi itu saja, tetapi juga telah melakukan promosi di media elektronik seperti radio yang ada dalam kecamatan Muara Bulian. Kegiatan promosi ini sudah baik, hanya saja kurang dilakukan pada setiap bulannya, maka untuk itu agar perusahaan Shopie Paris Bc. Yenni Kecamatan Muara Bulian dapat meningkatkan kegiatan promosi.

Analisa Strategi People, Dikarenakan Shopie Paris merupakan perusahaan multi level marketing (MLM) maka karyawannya berasal dari pendaftaran member, dengan adanya member maka usaha ini lebih akan cepat dikenal atau diketahui oleh setiap kalangan masyarakat baik yang dari kalangan anakanak, dewasa dan orang tua, member Shopie Paris Bc. Yenni Kecamatan Muara Bulian selalu meningkat. Maka berdampak pada peningkatan volume penjualan di Shopie Paris yang dikelola oleh ibu Yenni tergantung meningkatnya anggota member. Hanya tidak ada pelatihan bagaimana memasarkan produk Shopie Paris untuk member.

\section{SIMPULAN}

Berdasarkan hasil penelitian dapat disimpulkan sebagai berikut:

1. Starategi pemasaran dalam upaya meningkatkan volume penjualan pada Shopie Paris Bc. Yenni Kecamatan Muara Bulian, telah sesuai berdasarkan teori Kotler (2002) yaitu strategi produk, price, promosi, place dan people

2. Perkembangan penjualan produk Shopie Paris Bc. Yenni Kecamatan Muara Bulian selama 4 tahun terakhir pada tahun 2013 - 2016 kecuali pada tahun 2015 mengalami penurunan penjualan dengan nilai perkembangan penjualan sebesar Rp 1.800.000.000 sebesar $-0,5 \%$ yang disebabkan oleh menurunnya harga karet dan sawit yang berdampak pada volume penjualan Shopie Paris Bc. Yenni Kecamatan Muara Bulian, sedangkan pada tahun 2013 penjualan pada posisi tertinggi dengan nilai sebesar $0,2 \%$

3. Analisis strategi pemasaran dalam meningkatkan volume penjualan pada Shopie Paris Bc. Yenni Kecamatan Muara Bulian ialah strategi produk, price, promosi, place dan people

\section{DAFTAR PUSTAKA}

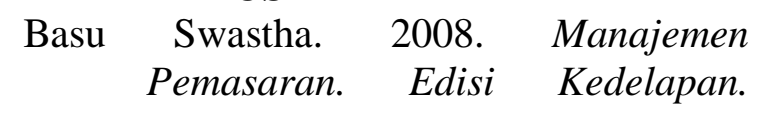


Cetakan Kedelapan. Penerbit

Liberty. Jakarta

Danang, Sunyoto. 2013. Manajemen

Pemasaran. CAPS. Yogyakarta

Hermawan. 2002. Marketing. Gramedia. Jakarta

Horne, Van, James. C and Wachowiz John. 2005. Fundamentals of Financial:

Management Prinsip- Prinsip

Manajemen Keuangan. Salemba

Empat. Jakarta

Husein Umar. 2005. Studi kelayakan Bisnis. PT Gramedia Pustaka Utama. Jakarta

Indriyo Gitosudarmo. 2001. Manajemen Pemasaran. Edisi II BPFE. Yogyakarta

Indriyo Gitosudarmo. 2008. Pengantar Bisnis Edisi 9. BPFE. Yogyakarta

Kasmir dan Jakfar. 2003. Studi Kelayakan Bisnis. Prenada Media. Jakarta

Kotler, Philip; Armstrong, Garry. 2008. Prinsip-prinsip Pemasaran, Jilid 1. Erlangga. Jakarta

Kuswara. 2005. Mengenal MLM Syariah. Qultum Media. Tangerang

Philip Kotler. 2002. Manajemen Pemasaran, Jilid 1, Edisi Milenium. Prehallindo. Jakarta

Philip Kotler. 2006. Manajemen Pemasaran Jilid I dan II, Edisi kesebelas. PT. Indeks Gramedia. Jakarta

Moleong. lexy. 2002. Metodologi Penelitian Kualitatif. PT remaja Rosdakarya. Bandung

Sofjan Assauri. 2007. Manajemen Pemasaran Konsep dan Strategi. PT. Raja Grafindo Persada.Jakarta 